\title{
Factors Influencing Employees' Commitment in the Public Institution: Empirical Evidences in Malaysia
}

\author{
Saraih, Ummi Naiemah ${ }^{1}$,Amlus, Mohd Harith ${ }^{2}$, Tunku Ahmad, Tunku Salha ${ }^{3}$ \& Abdulsatar \\ Abduljabbar Sultan ${ }^{4}$ \\ ${ }^{1,2,3}$ School of Business Innovation \& Technopreneurship, Universiti Malaysia Perlis, Malaysia \\ ${ }^{4}$ Department of Business Administration, Lebanese French University, Iraq
}

\begin{abstract}
This research is conducted to look on several factors which are expected to create an impact on employees' commitment in one of the public institution in Peninsular Malaysia. In specific, the aim of this research is to provide the linkages between organizational commitment and several factors in the perspectives of job performance, organizational justice and organizational citizenship behavior (OCB). Thus, the proposed research objectives are: 1) to identify the relationship between job performance and organizational commitment among employee in the public institution; 2) to explore the relationship between organizational justice and organizational commitment among employee in the public institution; and 3) to examine the relationship between OCB and organizational commitment among employee in the public institution. In accordance to that, a scientific literature review has been developed; and the participants of this research are included of 165 employees from one of the public institution located in the center region of Peninsular Malaysia. With the aid of SPSS software, the results indicated that all of the factors are positively and significantly related to organizational commitment among employee in this institution. The implications and several suggestions are discussed based on the research findings.
\end{abstract}

Key words: $O C B$, job performance, organizational commitment, organizational justice

\section{INTRODUCTION}

One of the major objective which is aimed by the Malaysia Public Service Department (PSD) is to formulate policies and guidelines relating to psychology services according to current needs to enhance human resource development in the public service (Public Service Department, 2019). This is parallel with PSD's slogan statement in improving governance, upholding accountability and transparency in Government administration. The PSD serves as the central agency in reforming the overall public services towards greater efficiency and effectiveness in both development and human resource management that inspire confidence and trust in the civil service among the people. However, as reported in the Public Complaints Bureau, customer satisfaction index from 1st January to 28th February 2019 reported that only $71.4 \%$ of customer satisfaction has been obtained even though the target percentage is documented as $90 \%$ for Year 2019 (Public Complaints Bureau, Prime Minister
Department, 2019). As reported, the number of customer complaints has been increased from 1102 cases $(14.1 \%)$ in 2018 , to 1297 cases $(17.7 \%)$ in 2019. Therefore, the greater efficiency and effectiveness of the human resource management (employees) can be obtained when the number of complaints can be reduced. This is expected can be linked to the high level of organizational commitment that should exist among employees in the public service institution. This claim is supported by [1] who presented that by increasing of several dimension of organizational commitment, it can make the level of employees' efficiency can be increased. Other researchers [2] also confirmed a significant association between the dimensions of organizational commitment and organizational effectiveness in their previous study.

Organizational commitment became essential to be investigated including in the public institution because it has the ability to increase the level of efficiency and effectiveness. To date, this research

Corresponding Author: Ummi Naiemah Saraih, Universiti Malaysia Perlis, School of Business Innovation \& Technopreneurship, Jalan Kangar-Arau, 01000, Kangar, Perlis, +6017.5080656 
attempts to provide the evidence that one of the factors which is related with organizational commitment is job performance. For instance, previous researchers stated that committed employees give a big contribution to organizations because they perform and behave on achieving organizational goals. In addition, [3] presented a significant correlation between commitment and job performance. Next, the second factor of organizational commitment as proposed in this research is organizational justice. For example, [4] empirical work resulted that organizational justice is the predictor of organizational commitment; and there was a positive, meaningful and a moderate relationship between organizational justice and organizational commitment. As added by these researchers [4], organizational justice explained approximately $41 \%$ of the total variance of the organizational commitment. The last factor of organizational commitment in this research is OCB. OCB is referred to the voluntary behavior that goes above the formal job description. Many efforts in the foreign country has been done to investigated the link between OCB and organizational commitment. One of them was presented by the previous study [5] which indicated that there was a significant relationship between OCB and organizational commitment.

Based on the above literature, factors such as of job performance, organizational justice and OCB are expected can trigger some influence to increase the level of organizational commitment among employee in the institution. Thus, this provide the basis of examining those factors (eg. job performance, organizational justice and OCB) and their relationship between organizational commitment among employee in the public institution. Given the above literature, the specific aims of this study are as follows:

1. To reveal the relationship between job performance and organizational commitment among employees in the Malaysian public institution.

2. To reveal the relationship between organizational justice and organizational commitment among employees in the Malaysian public institution. 3. To reveal the relationship between OCB and organizational commitment among employees in the Malaysian public institution.

\section{LITERATURE REVIEWS}

\section{Organizational Commitment}

The concept of organizational commitment is the main component of management issues of the organizations. There are different views in defining organizational commitment as different terms are applied to define this concept. Although various researchers have different views to commitment, most of them believe that there is a kind of affective and psychological attachment to the organization relating an individual and organization [2].

As stated by [6], in an organizational behavior perspective, organizational commitment is often defined as the level of employees' feeling of responsibility towards the organization. They added that some researchers described organizational commitment as a psychological attachment that created a remarkable relationship between an employee and the organization. They further added that organizational commitment has three components which are consisted of affective commitment (i.e. emotional connection to the organization); continuance commitment (i.e. perceived costs associated with leaving the organization); and normative commitment (i.e. feeling of obligation towards organization).

According to [4], affective commitment is emotional attachment to the organization, identification and involvement of an employee with the organization. Employees with strong affective commitment feel a strong commitment to the organization and do their best to achieve the goals. Meanwhile, continuance commitment relates to the costs associated with leaving the organization; and normative commitment is concerned with employee's feelings of obligation to remain in the organization, especially when they feel highly committed to the organization.

Taken together, in order for public institutions to achieve their efficiency and effectiveness, employees' commitment to their institutions and the output of their performance, the perception of justice and the extra role behavior or OCB may have significant influences to give rise to the presence of commitment is considered to play a major role. Therefore, it is very important to determine the effect of employees' commitment to the institution and their relationship with job performance, organizational justice and OCB. The basis foundation of proposing the theoretical framework for this research will be discussed in the next sub sections.

\section{Job Performance}

Various empirical studies emphasized on the effects of various organizational variables on organizational commitment; however, a few empirical studies are conducted on the survey of the effects of employees' performance on organizational commitment. As claimed by [7], the term performance was originally taken from the mechanics and sports fields, in order to subsequently be used to characterize the very good results also achieved in other fields (eg. 
organizational behavior field). This means that performance is obtained only by a limited number of entities, those who get the best results. Currently there are a variety of definitions attributed to the concept of performance due to its subjective nature. In the literature there are many articles or studies that define the concept of performance. As stated by [7], definition of performance should be achieved through items such as evaluation, piloting, efficiency, effectiveness and quality [8].

Existing literature also provided a link between job performance and organizational commitment. To date, [3] confirmed that a significant correlation existed between commitment and job performance. In addition, previous researchers [9] supported that a positive relationship is found between organizational commitment and employees' job performance. However, in this study, the researchers would like to provide a new knowledge on the consequences of job performance on organizational commitment. In other words, it is assumed that the level of commitment will be raised if the employees display the expected level of their job performance. Thus, H1 is formulated as: There is a significant relationship between job performance and organizational commitment among employee in the public institution.

\section{Organizational Justice}

According to [4], justice is one of the most important criteria in the social life. It is also the basis of all the correct behaviors. Although organizational justice is not a new concept in administration literature, but it is being neglected; however, when the related literature is analysed, we can see that organizational justice and organizational commitment are important concepts [4].

The analysis of the literature demonstrates that there are four dimensions of organizational justice, namely distributive justice, procedural justice, interpersonal justice and informational justice. As stated by [10], distributive justice is referred to employees' perception of fairness towards the organizational outcomes as they received from the organization; procedural justice is referred to procedures used to make those decisions of outcomes as given by the organization; interpersonal justice is referred to the treatment that employees received from the organization or its agents; and informational justice is referred to all required information related to various outcomes that provided by the organization.

In this study, the researchers attempt to test the impact of justice on organizational commitment among employees in one of the public institution. To date, organizational justice explained approximately $41 \%$ of the total variance in the organizational commitment [4]. Moreover, [11] presented that all of the components of the organizational justice effected organizational commitment and there was direct and significant relationship between organizational justice and its dimensions with organizational commitment. Thus, it become the basis for the researchers to proposed that when employees perceived the acceptable level of organizational justice, they will reciprocate to the organization by increasing their organizational commitment. Therefore, $\mathrm{H} 2$ is formulated as: There is a significant relationship between organizational justice and organizational commitment among employees in the public institution.

Organizational Citizenship Behavior (OCB) Organizations especially in the developing countries should provide opportunity for their managers and employees to use their experiences, abilities as well as their potential to improve organizational goals and this cannot come true until there is a suitable opportunity for OCB. As cited by [5], OCB is defined as the behavior which is discretionary and informal work environment to enhance profitability of the entire organization. Organ regards OCB as personal behaviors that are arbitrary and are not directly and clearly stated by formal testimonial system of organization which generally increases organization's efficiency. [12] proposed five OCB dimensions: altruism, conscientiousness, courtesy, civic virtue, and sportsmanship. In another study, [13] defined a two-factor OCB construct as OCB-I (OCB towards individuals) and OCB-O (OCB towards the organization), by combining Organ (1988)'s dimensions.

As stated by [14] OCB behavior comes in many distinct shapes and forms. It can also be the employee who takes the initiative and always offers to lend a hand; the knowledgeable, helpful and cooperative colleague; the senior staff member who is able to roll with the punches; or the friendly, approachable manager who shows the new employees around the office and introduces them to other staff. OCB refers to voluntary behavior that is not explains in formal job descriptions, but improve the efficiency and effectiveness of the organization.

In the aspect of the linkages between OCB and organizational justice, several authors revealed a significant relationship between both variables. For example, [5] claimed that OCB has a close relationship with organizational commitment, and indicated that OCB has a significant impact on organizational commitment. However, other researcher [15] found that organizational commitment influenced on OCB accordingly [15]. Their study tested organizational commitment and its consequences on employees' OCB. Meanwhile a study conducted by [16] revealed that there is no 
relation between organizational commitment and OCB. Thus, the relationship between these variables is still ambiguous and need a further exploration. In this study, it is expected that when employees display behavior which is considered to be discretionary and voluntary, thus it will help these employees to attach with a higher commitment to the organization. Given that, $\mathrm{H} 3$ is formulated as: There is a significant relationship between OCB and organizational commitment among employees in the public institution.

\section{METHODOLOGY}

The participants in the present study consisted of all employees in one of public institution located in the centre region of Malaysia. Data are obtained using questionnaires, in the self-perspective of rating. The information of job performance, organizational justice, OCB and organizational commitment is obtained from all employees in the institution. The questionnaires are distributed by the researchers to every participant in different sessions. The instrumentations for all variables have been adapted from different authors. The Cronbach Alpha values for all variables are presented in Table 1.

Table 1: Instrumentation and Reliability

\begin{tabular}{|c|c|c|c|}
\hline Variables & $\begin{array}{l}\text { Number } \\
\text { of Items }\end{array}$ & Authors (Year) & $\mathbf{A}$ \\
\hline $\begin{array}{l}\text { Organizational } \\
\text { Commitment }\end{array}$ & 8 & $\begin{array}{c}\text { Mowday, } \\
\text { Steers \& } \\
\text { Porter (1979) }\end{array}$ & 0.879 \\
\hline $\begin{array}{l}\text { Job } \\
\text { Performance }\end{array}$ & 7 & $\begin{array}{l}\text { Williams \& } \\
\text { Anderson } \\
\text { (1991) }\end{array}$ & 0.767 \\
\hline $\begin{array}{l}\text { Organizational } \\
\text { Justice }\end{array}$ & 7 & $\begin{array}{c}\text { Mobley, } \\
\text { Horner \& } \\
\text { Hollingsworth } \\
\text { (1978) }\end{array}$ & 0.935 \\
\hline OCB & 5 & $\begin{array}{c}\text { Schaufeli \& } \\
\text { Bakker (2003) }\end{array}$ & 0.826 \\
\hline
\end{tabular}

\section{FINDINGS AND DATA ANALYSES}

180 employees completed the questionnaires. When the returned questionnaires were examined, 15 were invalid. As a result, a total of 165 valid responses are used in this research which is contributed for $91.66 \%$. The sample included of $61.7 \%$ female and $46(38.3 \%)$ male employees; $85 \%$ of the participants were married, (11\%) were single, and $4 \%$ were divorced. The majority of the participants are in the ages ranged from 31 to 45 years of age, and the least group of the participants are in the ages above 45 years old.

Correlation analyses presented a positive meaningful correlation between the all of the tested variables (see Table 2). In specific, job performance has strongest positive significant influence towards organization commitment with $(\mathrm{r}=0.683, \mathrm{p}<0.01)$. Subsequently, the second strongest positive significant towards organization commitment is organization justice with $(r=0.578, \mathrm{p}<0.01)$. Next, the result of OCB and organization commitment showed the weakest significant correlation among all predictors to organizational commitment with ( $\mathrm{r}$ $=0.457, \mathrm{p}<0.01$ ).

Table 2: Inter-correlation between Variables

\begin{tabular}{lcccc}
\hline \multicolumn{1}{c}{ Variables } & $\mathbf{1}$ & $\mathbf{2}$ & $\mathbf{3}$ & $\mathbf{4}$ \\
\hline 1. Organizational & - & & \\
Commitment & & & \\
2. Job & 0.683 & - & \\
Performance & $* *$ & & & \\
3. Organizational & 0.578 & $0.599 * *$ & - \\
Justice & $* *$ & & & \\
4. OCB & 0.457 & $0.408 * *$ & $0.478 * *$ & - \\
& $* *$ & & & \\
** Correlation is significant at the .01 level (2-tailed)
\end{tabular}

Regression analyses resented a significant relationship between all of the predictors (job performance, organizational justice, OCB) and organizational commitment (see Table 3). Based on the results, job performance appeared as the strongest predictor to influence organizational commitment among employees in this public institution with $(\beta=.495, \mathrm{t}=5.571, \mathrm{p}=.050)$. The second strongest predictor of organizational commitment based on this study is organization justice $(\beta=.207, t=2.243, p=.050)$; followed by OCB $(\beta=.156, t=1.930, p=.027)$. Therefore, all hypotheses are accepted in this study.

Based on the $\mathrm{R}^{2}$ value, it is indicated that $52.9 \%$ of the total variance in organization commitment among employees in this institution is explained by job performance, organizational justice and OCB. In 
other hand, other $47.1 \%$ of the variance in organization commitment is explained by other factor. The value of $\mathrm{F}$ is reported at 35.927.
Table 3: Regression Analysis of Job Performance, Organizational Justice and OCB towards Organizational Commitment

\begin{tabular}{|l|c|c|c|c|c|c|}
\hline & $\mathbf{B}$ & $\mathbf{t}$ & $\mathbf{p}$ & $\mathbf{R}^{\mathbf{2}}$ & $\mathbf{R}^{\mathbf{2}} \boldsymbol{\Delta}$ & $\mathbf{F}$ \\
\hline $\begin{array}{l}\text { Job } \\
\text { Performance }\end{array}$ & 0.495 & 5.571 & $.050^{*}$ & 0.027 & 0.529 & 35.927 \\
\hline $\begin{array}{l}\text { Organizational } \\
\text { Justice }\end{array}$ & 0.207 & 2.243 & $.050^{*}$ & & & \\
\hline OCB & 0.156 & 1.930 & $.027^{*}$ & & & \\
\hline
\end{tabular}

$* \mathrm{p}<0.05: * * \mathrm{p}<0.01$

\section{CONCLUSION}

The finding for $\mathrm{H} 1$ indicated that job performance has a strong and significant influence on organizational commitment among employees in this institution with $\beta=.495^{*}$. This implies that employees in this institution have the abilities to performance the required job as expected in their description and their performance influence the high commitment of them towards the organizational. This finding is consistent with the previous study [3].

Some activities which can be supported by the management to let they can maintain a good level of performance are: 1) To encourage employees adequately completed their assigned duties; 2) To enforce employees to be engaged in activities that can affected their performance evaluation; and 3) To provide a working environment which employees can achieve the formal performance as per required in their job.

The finding for $\mathrm{H} 2$ also showed that organizational justice has a strong and significant influence on organizational commitment among employees in this institution with $\beta=.207^{*}$. This implies that employees in this institution have the acceptable level of perceived justice towards the organization and their justice perception created a significant influence on their commitment towards the organizational. This finding is consistent with the previous study [4].

Some activities which can be channeled to the management to continue the existence of perceived justice are: 1) The management needs to fairly rewarded employees by considering the responsibilities they have; 2) The management needs to fairly rewarded employees by considering the education and training they have; and 3) The management needs to fairly rewarded employees by considering the stresses or any strains they faced in accomplished their job.

Third, the finding for $\mathrm{H} 3$ also confirmed that OCB has a strong and significant influence on organizational commitment among employees in this institution with $\beta=.156^{*}$. This implies that employees in this institution have a good level of discretionary and voluntary behavior which goes above their formal job requirement and these behaviors are very significant in increasing the level of their commitment towards the organizational. This finding is consistent with the previous study [5].

Some activities which can be suggested to the management to continue the appearance of OCB among the employees are: 1) The management needs to encourage employees give their time to help colleague who have work-related problems; 2) The management needs to convince employees to willingly take their time out of my own busy schedule to help new colleague; and 3) The management needs to advise an action to let employees can take steps to prevent problems with other personnel in the company.

\section{REFERENCES}

[1] Salman, M., Pourmehdi, K. \& Hamidi, N. (2014). Examine the relationship between organizational commitment effectiveness and employee efficiency of Qazvin Agricultural Organization. International Journal of Research in Social Sciences, 4(3), 131-147.

[2] Ahmadi, A. \& Donuqezelbash, H. (2013). A survey of the effect of staff's organizational commitment on effectiveness in municipalities of Yazd Province. European Online Journal of Natural and Social Sciences, 2(3), 8-17.

[3] Rebecca, C. T. (2013). Organizational Commitment and Job Performance of the Academic and Administrative Personnel. International Journal of Information Technology and Business Management, 15(1), 51-59.

[4] Buluc, B. \& Gunes, A. M. (2014). Relationship between organizational justice and organizational commitment in primary schools. Anthropologist, 18(1), 145-152.

[5] Hasani, K., Boroujerdi, S. S. \& Sheikhesmaeili, S. (2013). The effect of 
organizational citizenship behavior on organizational commitment. Global Business Perspective, 1, 452-470.

[6] Ismail, A. \& Abdul Razak. M. R. (2016). Effect of job satisfaction on organizational commitment. Management \& Marketing, 14(1), 25-40.

[7] Elena-Iuliana, I. \& Maria, C. (2016). Organizational performance: A concept that self-seek to find itself. Academia Brancusi Publisher, Economy Series (4), 177-183.

[8] Bartoli A. \& Blatrix C. (2015). Management dans les organizations publiques (4ème edition), Management in Public Organizations, Dunod, Paris.

[9] Khan, M. R., Ziauddin, Z. Jam, F. A. \& Ramay, M. I. (2010). The impacts of organizational commitment on employee job performance. European Journal of Social Sciences, 15, 292298.

[10] Saraih, U. N., Mohd Karim, K., Abu Samah, I. H., Amlus, M. H. \& Abashah, A. N. (2018). Relationships between trust, organizational justice and performance appraisal satisfaction: Evidence from Public Higher Educational Institution in Malaysia. International Journal of Engineering \& Technology, 7(2.29), 602-606.

[11] Rafei-Dehkordi, F., Mohammadi, M. \& Yektayar, M. (2013). Relationship of organizational justice and organizational commitment of the staff in general directorate of youth and sports in Chahar Mahal Va Bakhtiari Province. European Journal of Experimental Biology, 3(3), 696-700.

[12] Organ, D. W. (1988). Organizational citizenship behavior: The good soldier syndrome. Lexington, MA: Lexington.

[13] Williams, L. J. \& Anderson, S. E. (1991). Job satisfaction and organizational commitment as predictors of organizational citizenship and inrole behaviors. Journal of Management, 17(3), 601-617.

[14] Saraih, U. N., Zin Aris, A. Z., Mohd Karim, K., Abu Samah, I. H., Syaaban, S. \& Abdul Mutalib, S. (2017). Relationships between organizational commitment, OCB, organizational justice and turnover intention: Evidences from Educational Institution in Malaysia. Review Integrative Business \& Economics Research, 6(2), 64-77.

[15] Mirabizadeh, M., \& Gheitasi, S. (2012). Examining the organizational citizenship behavior as the outcome of organizational commitment: Case study of universities in Ilam. Management Science Letters, 2(3), 951960.

[16] Mehrabi, J., Alemzadeh, M., Jadidi, M., \& Mahdevar, N. (2013). Explaining the relation between organizational commitment and dimensions of organizational citizenship behavior case study: Textile Factories in Borujerd County. Interdisciplinary Journal of Contemporary Research in Business, 5(8), 121132. 